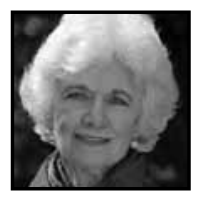

\title{
Commentary
}

\section{Enthusiasts for Learning: Leaders in Creativity}

\author{
Shirley Brice Heath
}

\begin{abstract}
This commentary points to several movements in modern economies that support informal or voluntary learning. A historical context establishes reasons for the rise of professional amateurs, such as citizen scientists, community youth arts organizations, and do-it-yourself individuals and groups. Creativity marks the nature of learning among voluntary learners, as does dedication to open sourcing. Shared knowledge at the citizen/consumer level benefits everyone. Within this atmosphere, young people are drawn to follow through on problems and issues by seeking information, guidance, and demonstration from sources of expertise on the Internet, in their communities and schools, and among others similarly enthused about learning on one's own in one's own way.
\end{abstract}

am an anthropologist who has spent the past thirty years studying how children and young people spend their own time learning. ${ }^{1}$ When people learn of my long-term pursuit, they ask questions: What do children and teenagers do that is real learning? How do they do it? How have societies changed in their ways of supporting, fearing, and ignoring learners who want to learn on their own time and in their own way toward creative projects, processes, and performances?

Here I answer some of these questions. I place them in a brief historical context that helps explain the fact that in $2011,85 \%$ of US employers searching for creative talents reported that they could not find individuals with these skill sets. In the same year, employers in the computer science field identified creativity as the top leadership competency. In 2010, the United Nations suggested that the most creative nations would be the most resilient. In these same years, the public media frequently 
speculated on the dire consequences that could result from entertainment's takeover of children's free play and flexible opportunities to explore nature and to create imaginative projects. If the "future favors the flexible," then what? (Richardson, 2011).

\section{National Awakenings}

In 2004, the Demos Foundation in London published a small volume entitled The Pro-am Revolution: How Enthusiasts Are Changing Our Economy and Society (Leadbeater \& Miller, 2004). The authors, both economists and political theorists, had long been public intellectuals thinking about ways to engage the British populace in local development of creative industries. Within a year after the slim volume on "the pro-am revolution" appeared, the British anthropologist Ruth Finnegan edited a collection of papers entitled "Participating in the Knowledge Society" (Finnegan, 2005). The papers detailed more than a dozen types of pursuits ranging from archaeology to software design to ornithology through which the special interests of voluntary learners enabled them to accumulate information, invent new free services and products, and band together to solve local problems.

These publications awakened widespread interest in how individuals living in modern economies learn on their own time and in their own way and come together to create the multiplier effect of their collective learning. Since 2005, productions and publications of all types and in a variety of modes have hosted a steady flow of films, plays, articles, opinion pieces, and calls to action. Individuals in small groups now network across national and linguistic boundaries to advance scientific understanding of bird migration patterns, ocean pollution, and disaster control and to extend the boundaries of art forms from different cultures. These groups increasingly include young people who are drawn to the flexibility and diversity of contexts in which they and others work and learn creatively. As the Arab Spring of 2011 showed the world, such groups can bring about political revolutions.

\section{A New Century, New Ways of Learning}

The final decades of the 20th century saw a dramatic increase in the percentage of young people living in modern economies who headed into formal higher education. Public policy and education leaders pushed hard the idea that all students should set as their goal completion of a college or university degree. Passing tests and being certified and legitimated by a higher education institution brought the promise of a lucrative job. Becoming a professional seemed the only way for young people to prepare for careers. Public media repeatedly pointed to the global economy's 
need for professionals in medicine, engineering, finance, economics, climate change, biotechnology, computer science, and law. Trained and legitimated through years of specialized schooling meant that these professionals reflected standards and could be expected to advance the bottom line for corporations now marketing around the world. Licensing, certification, and gradations of expertise were an accepted addendum to achievement of a degree in higher education. Whether a new employee of a corporation or an enterprising entrepreneur, individuals were expected to prove themselves as professionals through satisfactory performance in apprenticeships, internships, clerkships, or state professional examinations.

Within the first few years of the opening of the 21st century, however, degrees and certification no longer guaranteed the lucrative positions that young educated men and women had held during the 1990s. Just as young people could no longer take six-figure salaries plus bonuses for granted, a silent movement gained speed and force in local communities. Without fanfare, individuals across the age span were turning to voluntary expertise development during their leisure time. They were doing so by going over and around the walls of institutions. Their enthusiasms, whether citizen science, visual arts, open-source software development, water-saving inventions, or alternative health practices, took them into social networks far away from their usual professional circles. On their own time, citizens, young and old, identified needs, followed their interests, and determined ways to know and do in their spare time what neither commercial nor civic institutions and organizations were undertaking. Those who stayed with their voluntary learning pursuits easily logged the proverbial 10,000 hours that author Malcolm Gladwell had posited as the tipping point into success (Gladwell, 2008). Success for diy-ers (do-it-yourself-ers) meant learning to do something on one's own by practicing, studying, talking, and traveling to meet and join with other enthusiasts with similar goals. Ways to learn meant enrolling in formal classes, arranging get-togethers at one another's homes, searching the Internet, risking trial-and-error sessions with a local friend, initiating spontaneous conversations in coffee shops and bookstores, and attending special interest shows and conventions. Those who became "pro-ams" or professional amateurs used both conventional and unconventional ways to find resources, models, experts, and histories of the work of experts from past eras.

International changes in Internet access multiplied the numbers and types of knowledgeable individuals to which learners had access. Many made no secret of their goal of subverting certain corporate and institutional ways of creating products and services, carrying out research, exerting control over creativity, and compiling and storing information. For example, the independent music industry, starting 
with rap and expanding to other genres, prefaced the move to diy ways of getting music to consumers by making their work freely available on the Internet. Independent filmmakers followed a similar course. Novelists, such as Stephen King, led the way for authors when he experimented with making portions of his work openly and freely available on the Internet. Software developers, who had been among the first to advocate open sourcing, relished the public fanfare that accompanied the growth of the "indie" movement in film, music, and other arenas of commerce previously controlled by large corporations.

Meanwhile, pro-ams across the lifespan of learning took note of widely publicized efforts to subvert powerful commercial entities that played largely to shareholder dictates and higher profits. Adult pro-ams urged young people to be pro-ams and to work to professional standards while simultaneously innovating, challenging, and taking risks to test their ideas with others. The free and open distribution of expertise marked small groupings of learners, young and old, dedicated to similar interests and willing to commit to unending practice and experimentation. These learners saw themselves as making play work for themselves and for society as a whole (Brown, 2009).

As the first decade of the 21st century came to an end, employers and economists pointed to the desperate need in modern economies for workers who knew how to collaborate, develop and think through creative ideas, and work "outside the box." To be sure, the fundamental criteria for becoming an effective employee remained just as they had been outlined in national reports from economic bureaus more than a decade earlier (e.g., Secretary's Commission on Achieving Necessary Skills, 2004). But these reports emphasized what employers wanted from schools and not what young people could and did set out to learn on their own and with other learning enthusiasts. The quiet revolutionary shifts to what many termed "informal learning" had not yet entered mainstream thinking.

On their own time and in their own way, enthusiast learners explored information sources and tested creative ideas that extended far beyond the time and curricular restraints of formal education settings. Voluntary learners built their expertise and developed their creative ideas by observing closely what others were doing and had done. They worked with new combinations of processes and raw materials in their work. They expanded much of what they had learned in their formal schooling even as they drew from non-schooled experts who had learned early in their lives to work outside the "normal" way of doing things. 


\section{Young People in the Play and Work of Creativity}

Children and adolescents express their creativity in ways that differ from and complement the means and modes of creative groups of adults. The individual creative young person is inclined to move toward some product or process of innovation through long periods of silent thinking, reflecting, and sketching out ideas. These individuals learn as visualizers. In addition, they are gleaners, for they have wideranging interests that lead them to collect and sort bits and pieces of information. They vacillate between wanting to make the simple complex and to ensure that the complex is very simple. They are both builders and destroyers in their play and work. They have an inclination to seek out and define problems and a resistance to solving problems that other people set before them. Learners drawn to testing their ideas out often spend long periods of time alone, doing activities not seen as particularly worthwhile by others. They are fundamental questioners and resisters. These learners tend toward taking risks, trying out the untried, going the uncharted or dissonant route, and choosing to practice almost endlessly specific skills related to one or another core interest at any point in time. They are risk-takers who have a self-starting mechanism that others find hard to turn on or off. Therefore, others often characterize them as "unpredictable" or "hard to control."

When these young individual learners come together into groups to play and work collaboratively toward a creative product or performance, individuals watch as their ideas are confirmed, contradicted, and amplified by others. Creative groups tend to be marked by a tendency to work best under very tight and high-risk deadlines. These youthful groups believe that whatever they do, meaningful consequences and outcomes will result for the group.

The need for external critique of both process and product or performance is acknowledged, though sometimes resisted. Group members challenge their advisors; in doing so, they advance their learning and find new ways to test their ideas. Creative groups demonstrate willingness to value contributions of disparate types of information and out-of-the-ordinary ways of doing things.

Increasingly, young people find on the Internet new models for how they want to learn. Adolescents, often those who do not find themselves engaged and enthused about classroom life, begin to seek new ways to expand their interests. In doing so, they naturally find themselves drawn to horizontal ways of learning that rely on a widening and increasingly diverse range of types of authority, modes of representation, time frames, and norms of achievement. Their learning involves tinkering, puttering, trying, talking, testing, and redoing. Many young people begin with one 
interest or passion and then switch to another that may draw only indirectly from the original impetus for their learning. Moving in a new direction and switching back and forth across interests marks the learning of young learning enthusiasts as they work their way into the arenas of expertise they most want to develop. For example, young people who begin their interests in computer programming by immersing themselves in video games often tire of this mode and turn to one or another particular aspect of graphic design. A young would-be scientist who starts her rebellious interest in motorcycles may lose this passion and turn instead to intensive participation with a neighborhood dad who is a physicist, robotics enthusiast, and uncle of two "cool" teenage boys.

As the second decade of the 21 st century opens, foundations, corporations, community organizations, libraries, and summer programs sponsored by universities show some few signs of recognizing the value of informal learning to the development and promotion of creativity in modern economies. As this recognition grows, resources may become more and more available, but they are sure to come slowly and quietly. However, as opportunities and resources spread, young people will want to maintain control over their own learning. They will only cautiously look to others to help provide them what they most need to advance their creative play and work. Their needs include the following:

1) material items to support creative work (e.g., for robotics)

2) linkage with previously inaccessible sources of information and ideas

3) opportunities to observe and participate with experts in their spaces (e.g., laboratories, studios, rehearsal zones)

4) openings to allow young people to align with expert adults interested in the same project over several years (e.g., profit-making use of recycled materials)

5) intensified access to software enabling highly specialized modeling and testing of mathematical and artistic ideas (e.g., in astronomy)

6) widened involvement in debates surrounding patent applications and the entrepreneurial potential of innovations

\section{Knowledge Societies}

The label "knowledge society" is rapidly being applied to more nations around the world. Canada, the United States, Australia, and European nations now find themselves being outpaced in out-of-the-box practices in which individuals of nations such as China, India, and Brazil excel. Some of these practices, such as hacking, amount to theft and destruction. Others, such as extraction and cultivation of 
medicinal herbs, challenge the positioning of pharmaceutical corporations. Young pro-ams relish keeping track of these practices, and often play with ways to identify hackers, design anti-hacking programs, and combine security measures in new ways. Intel Science winners in the US study animal behaviors and plant components in other parts of the world in order to propose their uses to replace expensive means or products used in modern economies (see, for example, the case studies in Dutton, 2010). Young social entrepreneurs find ways to identify their counterparts in nations around the world, sharing ideas and plugging practices through Internet communication.

Leaders of democratic nations that experienced the economic recession of the first decade of the 21 st century were hit with the harsh lesson that governments and their institutions previously expected to "serve" the people could no longer do so. Economic returns through taxes did not match needs. Citizens would not only have to be more productive in their work settings but also would need to be responsible for themselves in more ways. Citizens would need to dedicate their attention and activism to highly specific problems, such as water quality, loss of local wildlife resources, and invasion of new species of insects attacking local crops.

Previously, research behind such issues fell to governmental agencies and university research teams, often funded by governmental grants. As the 21 st century moves forward, citizen pro-ams will be doing more and more monitoring of local needs and devising ways to meet these in relation to the availability of local expertsmany of whom will have voluntarily chosen to learn the knowledge and skills called for to meet local needs.

General use of the term "informal learning" rarely captures the varieties of ways that knowledge and skill acquisition go on with pro-ams. The majority of discussions of "informal learning" describe it as learning that is undertaken by individuals and groups who study and experiment outside formal settings of instruction. However, pro-ams and experiential learners across the lifespan see formal contexts as merely one possible way of learning that will increasingly be needed to complement previously common ways of pursuing inventions, innovative strategies, niches of interest, and specialized ways of combining modes of representation (Heath, 2012).

Pro-ams, though driven in the main by interest in stepping outside the usual ways of doing and knowing, also find their motivation in what they see as a need. Sometimes they may begin their work to meet their own individual need or to follow up on a matter of mere curiosity. However, as they advance their learning, they 
accumulate contacts with others who may be in the midst of similar pursuits. In the first decade of the 21st century, pro-ams came increasingly to be motivated by the needs of impoverished and needy groups whose interests were not being served by either institutions such as schools and governments, or corporations such as pharmaceuticals and medical device distributors.

Young people continue to see parallel needs in the lack of resources and spaces for learning that children and adolescents experience when they live in underresourced neighborhoods both local and distant. Simultaneous with the rise of proam enthusiasts for learning was acceleration in social entrepreneurial and blendedvalue projects that allowed for-profit accumulation of assets along with non-profit pursuits. Widely proclaimed in the public press and elaborated in youth-based urban projects, such entities often found ways to partner with civic, medical, and educational institutions. For example, Artists for Humanity, a youth initiative in Boston, Massachusetts begun in 1991, emerged by 2005 as a regular client of the city, as well as commercial businesses in the area. The young artists (between 14-18 years of age) were commissioned to design benches, bicycle racks, and other objects the city needed, while commercial businesses enlisted Artists for Humanity to design websites, create advertising materials, or develop a portfolio of photographs for use in waiting rooms and lobbies. A medical clinic besieged with young patients with early-onset diabetes enlisted the young artists to create educational materials on the disease that would be "cool," explanatory, and persuasive (http://www.afhboston.com).

Across modern economies, young people have either started their own learning environments to accommodate their interests and needs or they have sought out leaders of museums, parks, and other community groups and persuaded them to ramp up their emphasis on voluntary learning by the young (see, for example, Elizabeth \& Young, 2006). In order to support themselves, young-initiated organizations have relied on adults with expertise in specialized niches of interest the young were keen to learn. Dominant among the primary activities of these organizations were art forms, such as graphic arts, sculpture, furniture and fashion design, musical genres. Not far behind have been strong environmental interests, such as organic community garden development, recycling programs, and preservation of indigenous ways of using herbs and other plants (e.g., Gaylie, 2011). Leaders of museums, parks, and botanical gardens have been among the first community organizations to see themselves partnering with young people in these pursuits.

Why work and learn voluntarily? Any enthusiast will have some unique answers to this question. Most will agree, however, that having a sense of place in 
a world of fluid identities and memberships comes for them in the work and play they undertake. Voluntary learners, perhaps ironically, feel they belong to something greater than themselves and better than what the institutions around them provide. Voluntary learners value the resiliency that using their own time in their own way gives them. They know that what they do banks social and cultural capital for them as individuals and as groups, even when what they do faces resistance.

Finally, and perhaps most important, these enthusiast learners position themselves as critics, observers, and protectors of democracy. They take freedom seriously and wish that more people around them would do so as well. In short, they are dedicated to the idea that as the numbers of individual and groups who assert themselves as pro-ams go up, so does the measure of the freedom of the society (Dyson, 2002).

\section{Notes}

1. Unless otherwise noted, generalizations stated in this article are based on findings from Heath 2012 and publications cited in Heath's CV which can be found at www.shirleybriceheath.net.

\section{References}

Brown, S. (2009). Play. How it shapes the brain, opens the imagination, and invigorates the soul. New York: Penguin.

Dutton, J. (2011). Science fair season: Twelve kids, a robot named Scrooch... and what it takes to win. New York: Hyperion.

Dyson, F. J. (2002). "In praise of amateurs." The New York Review of Books. XLIX, no. 19, 5 December.

Elizabeth, L., \& Young, S. (Eds.). (2006). Works of heart: Building village through the arts. Oakland, CA: Newvillage Press.

Finnegan, R. (Ed.). (2005). Participating in the knowledge society: Researchers beyond the university walls. London: Palgrave Macmillan.
Gaylie, V. (2011). Roots and research in urban school gardens. New York: Peter Lang.

Gladwell, M. (2008). Outsiders: The story of success. New York: Little Brown.

Heath, S. B. (2012). Words at work and play: Three decades in family and community life. Cambridge: Cambridge University Press.

Leadbeater C., \& Miller, P. (2004). The pro-am revolution: How enthusiasts are changing our economy and our society. London: Demos.

Richardson, L. S. (2011). "Play power: How to turn around our creativity crisis." Atlantic Monthly. May 2, 2011. 


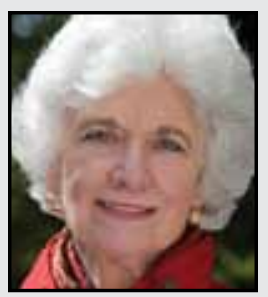

Shirley Brice Heath is the Margery Bailey Professor of English and Dramatic Literature, Emerita, and Professor of Linguistics, Emerita, at Stanford University. She was Professor at Large at Brown University from 2003-2010, and she has taught at universities in Australia, Europe, and Canada. She is particularly interested in how voluntary learning by not only young people but also citizens across the age span continuously adapts to meet the shifting needs of local communities in modern economies. Heath is the author of the classic, Ways With Words: Language, Life, and Work in Communities and Classrooms (1983/1996) and its sequel, Words at Work and Play: Three Decades in Family and Community Life (2012).

\section{LINKTO:}

http://www.shirleybriceheath.net 